Bilal Bourkha (France), Younes Belfellah (France)

\title{
Inter-organizational imitation: Definition and typology
}

\begin{abstract}
The sustained idea of this article is that the concept of imitation has not been sufficiently developed in the field of strategic management and has often been confused with the notion of mimicry. Therefore, the objective of this research is to emphasize the distinction between different types of imitation unlike a lot of research on companies imitative behavior focused on one type as the perfect imitation. This will clarify ambiguities in the literature on imitation, and show that the mobilization of neo institutional theory is not sufficient to explain all the imitative behavior of organizations in a market.
\end{abstract}

Keywords: imitation, mimicry, total imitation, partial imitation, creative imitation.

JEL Classification: L20, L21, L22.

Received on: $13^{\text {th }}$ of March, 2017.

Accepted on: 12 ${ }^{\text {th }}$ of April, 2017.

\section{Introduction}

Fifteen years after Levitt (1966) recommendations to researchers and to practitioners in management concerning the necessity to give more attention and value to imitation, the literature is still very poor on this subject. Levitt (1996) noted imitation does not receive the attention it deserve despite it importance in the business world. Nevertheless, it seems that in the last years researchers took Levitt advice into consideration as they give more attention to this phenomenon. In order to illustrate this new attitude regarding imitation, an examination on "Business Source Complete" database was realized between 1965 and 2013. It appears that the word "imitation" is only quoted as a keyword in 304 articles' title, whereas the word 'innovation' is quoted 34792 times. DeFillippi et al. (2008) explained this weak interest for imitation because of the abundance of researchers in business administration.

Researchers associate imitation to other terms and in particular to mimicry. One of the most mobilized theories to explain mimicry behaviors is the "neo institutional". We consider this theory is not enough to distinguish mimicry behaviors and imitative ones on competitive markets. In addition to the "neo institutional" theory, we mobilize the Theory of Reasoned Action (TRA)

C Sp. z o.o. Kozmenko Science Publishing, 2017.

Bilal Bourkha, Professor at Ecole Nationale de Commerce et de Gestion- Université Mohammed Premier Oujda-Maroc Laboratoire de Recherche en Gestion Appliquée et Intelligence Marketing, France.

Younes Belfellah, Ph.D. Student at Institut d'Administration des Entreprises de Pau- Bayonne- l'Université de Pau et des Pays de l'Adour (UPPA), France. and the mainstream of competitive interactions in order to define and clarify the notion of imitation between companies in a competitive market.

Research on imitation in management pertains strategic organizational decisions as alliance decisions, merger and acquisition, internationalization, innovation and new market penetration (Table 1).

Except the article of Haunschild (1993), in the literature there are no articles on imitation where imitation is clearly defined. A dominant part of those who worked on imitation link the observed similitude between products or the organizational practices to isomorphism by mobilizing the "neo institutional" theory. This theory was presented by Powel and DiMaggio (1983) in the famous founding article titled "The iron cage revisited: Institutional isomorphism and collective rationality in organizational fields" which was published in "American Sociological Review".

For the "neo-institutionalism", Mimicry is linked to a founding notion "organizational area" (DiMaggio \& Powell, 1983). In accordance with neo-institutional theory, organizations evaluating in the same organizational area develop common norms and have to achieve progressively similar behaviors. Homogenization can be understandable with isomorphism concept (DiMaggio \& Powelle, 1983). They suggest organizations evaluating in the same organizational area tend to be alike because since they develop more and more common norms, they have to achieve progressively similar behaviors. This similitude is the source on the one hand, of explicit rules or laws to assure this mechanism of convergence, and the other hand, usual activities implied by norms, values, with a cultural expectation or by the willingness to look like the others. 
Table 1. The imitation and organizational of life

\begin{tabular}{|l|l|l|l|}
\hline \multicolumn{1}{|c|}{ Articles } & \multicolumn{1}{|c|}{ Phenomena } & \multicolumn{1}{c|}{ Samples } & \multicolumn{1}{c|}{ Contributions } \\
\hline Haunschild (1993) & Acquisitions & $\begin{array}{l}327 \text { American firms in 4 } \\
\text { industries }\end{array}$ & $\begin{array}{l}\text { Companies imitate in order to determine their acquisition politic } \\
\text { when managers sit on other firms' boards }\end{array}$ \\
\hline Haveman (1993) & $\begin{array}{l}\text { Decision to enter into new } \\
\text { markets }\end{array}$ & $\begin{array}{l}313 \text { American saving and } \\
\text { operating loans associations }\end{array}$ & $\begin{array}{l}\text { American loan agents tend to replicate the decisions to enter into } \\
\text { new markets based on their most performing competitors }\end{array}$ \\
\hline Haunschild et al. (2007) & New products introduction & $\begin{array}{l}429 \text { new product introduction of } \\
67 \text { firms in in the US digital } \\
\text { camera market }\end{array}$ & $\begin{array}{l}\text { Cameras' introduction in the US can be widely explained the } \\
\text { presence of imitation behavior }\end{array}$ \\
\hline Sirmon et al. (2008) & $\begin{array}{l}\text { Decision to invest in R\&D } \\
\text { and in internationalization }\end{array}$ & $\begin{array}{l}\text { Manufacturer industry (French } \\
\text { SME) }\end{array}$ & $\begin{array}{l}\text { The imitative behaviors of companies influence the decision to } \\
\text { invest in R\&D and in internationalization }\end{array}$ \\
\hline Mouricou (2009) & Programming decision & 31 French musical radios & $\begin{array}{l}\text { Broadcasters' practices of competitive imitation are part of the } \\
\text { strategy of French musical radios. These practices result from the } \\
\text { programmer's doubts and perception of uncertainty }\end{array}$ \\
\hline $\begin{array}{l}\text { Anderson \& Semadeni } \\
\text { (2010) }\end{array}$ & Organizational innovation & $\begin{array}{l}50 \text { largest management } \\
\text { consulting firms }\end{array}$ & $\begin{array}{l}\text { Organizational innovation is linked to questions such as imitation } \\
\text { and the market expectations }\end{array}$ \\
\hline Ghalia (2011) & Development strategy & $\begin{array}{l}\text { French food-processing } \\
\text { industry }\end{array}$ & $\begin{array}{l}\text { The imitation is a strategy allowing to meet the expectations of food- } \\
\text { processing markets and to develop this industry }\end{array}$ \\
\hline Ghani (2012) & Decision to adopt ERP & Moroccan SME & The imitation explains the ERP adoption by Moroccan SME \\
\hline
\end{tabular}

DiMaggio and Powell (1983) mobilize the term "isomorphism" to describe the likeness (resemblance) between organizations. They emphasized the uncertainty can be considered as an indicator of imitation behavior ("mimicry isomorphism"). They have also developed two other pressures (coercive and normative), which can be a source of isomorphism. However, they cannot be a source of imitation since organizations are isomorphs; on the one hand, they behave in an identical way; one the other hand, they copy intentionality an action from competitors. Fligstein (1991) explain this phenomenon of mimicry isomorphism by the institutional context (organizations, customers, suppliers, public organizations) that creates a pressure upon the organizations. These pressures lead to alignment and adaptation of organization. If isomorphism is an observable result within a population, thus mimicry is the processes that lead to this result.

Mimicry or mimicry isomorphism are two concepts generally used for all situations where organizational actions are homogenous. Regarding particular researches, distinction between mimicry and other terms like imitation is not that obvious (Mouricou, 2009). Clarification of this fuzziness is one of the aims of this article. This school of thought considers imitation as a characteristic of reactions in competitive markets (Chen, 1988; Smith et al., 1989, 1991). In other words, it is the similitude level between a reaction and an action that defines the reaction type and its competitive intensity. The cross-reference to this trend allows distinguishing various types of imitation or competitive reactions on the one hand; and presenting imitation in a dimension different from a basic reproduction of innovation. Moreover, the
Theory of Reasoned Action (TRA) (Fishbein \& Ajzen, 1975) considers that human behavior is determined by the intention to adopt the behavior. Based on these two approaches, it is suggested that similitude in competitive markets can be explained by something different from isomorphism. Mobilization of these two approaches, according to us, will allow clarifying the notion of imitation. In particular this will help to distinguish this notion from mimicry notion, which is the mean/principal objective of this article.

During this work, we are willing to identify the different types of imitation in the literature. As opposed to neo-institutionalist researchers who suggest organizational similarities are due to isomorphism; competitive imitation is observed between organizations that are not subjected to pressures. Thus, they have neither to find a solution nor to adapt to any pressure.

\section{Imitation and mimicry. What is the specificity of each term?}

The definition of imitation is different from a researcher to another according to the theoretical membership. For instance, imitation for researchers in marketing is forgery or the homogeneity of a product's characteristics (Carpenter \& Nakamoto, 1989). In innovation field, imitation refers to a new technology imitation (Damanpour, 1991). Researchers often speak about legal systems and intellectual property rights to protect innovations. In sociology (neo institutional theory), imitation is considered as a simple organizational behavior with the project to acquire legitimacy in an organizational field (DiMaggio \& Powell, 1983). In economy, imitation is considered either a generator of competitive movements (Tirole, 1990) or a 
rational decision taken based upon results and information available in an environment (Banerjee, 1992). Currently, with resource approach domination, speaking about imitation may generate a discussion on resources and abilities for a researcher in management. An organization can sustain a competitive advantage only if it has precious, rare, inimitable and non-substitutable resources (Barney, 1991). Or, if this sustainable competitive advantage is the result of a unique dynamic ability, that is inimitable and non replicable (Teece et al., 1997). In this perspective, imitation depends on the interaction between resources and causal ambiguity (DeFillipi \& Reed, 1990). It is also considered as a threat to be avoided in order to get a competitive advantage (Porter, 1986); as a way to acquire experience from the others (Lewitt \& March, 1988); or even as a characteristic of a competitive reaction (Bensebaa, 2000).

According to Haunschild (1993), a practice is considered as the result of imitation if it fulfills the three following conditions: "(1) a model company presenting this practice in the time, (2) company representatives are exposed to the model, (3) the imitative company exposes the practice in the time $t+x$, where $x$ is a positive period of time". These conditions have been used by many researchers in management to justify the presence of imitative behaviors in markets. However, these ones seem to be insufficient to show that a practice adopted by an imitative company is the result of imitation only. Powell and DiMaggio (1983) clarified institutional pressures as the unique explicative factors of homogenization between organizations. These conditions were used by few researchers in management to justify the presence of imitative behaviors on markets. Nevertheless, we consider this justification insufficient to show that a practice adopted by an imitative organization is the result of an imitation; and not the result of institutional pressures such as the only explicative factors as presented by Powell and DiMaggio (1983).

Contrary to the reasoning of Haunschild (1993), an adoption of a company practice at $t+x$ does not mean necessarily an imitation. Companies pursue simultaneously and independently the same innovative practices and products. When a company launches it innovation competitors come to present their own innovations. Similitude between products upon a market is not linked consistently to imitation. For instance in Formula 1, IAF (International Automobile Federation) imposes every year new rules to car manufacturers. Consequently, car manufacturers are, simultaneously and independently, seeking to develop new techniques based on the respect of new rules. After the cars' presentation at the beginning of each season, technical similarities are often noticed. For instance, Maclaren and Ferrari used the same pontoon on their 2012 cars without having imitated one another. This example illustrates that the similitude between organizations can result of common rules to be respected on the market and not of imitative behaviors. Another example concerning industrial espionage can call into question Haunschild's reasoning. Actually, companies can adopt a practice at time $t$ while having recourse to industrial espionage so as to take advantage from competitors' degree of progress. Moreover, these companies can be able to take action first or in the same moment in the market. Thus, time factor is not significant by itself to distinguish between imitation, espionage and piracy. It's for this reason that we consider Haunschild's conditions (1993) are not significant to take for granted a competitive reaction on a market like an imitative reaction.

In order to distinguish between imitation and mimicry, Baudounnière (1997) introduced a condition of intention in so far imitation behavior is the result of an intention to replicate an innovation before acting as opposed to mimicry behavior. Support the idea that a similitude between products and organizational practices is the result of an imitation and not mimicry implies organizations intended to imitate and have reasons to behave as imitative. Hedström (1998) described this argument as a "rational imitation". The origin of this association between imitation intention and imitation can be found in Reasoned Action Theory, developed by Fishbein and Ajzen (1975). This theory considers individuals' behavior is determined by the intention. Hartwick and Barki (1994) revealed that adoption behavior of information technologies by organizations is determined by the attitude and the subjective norm of organizational staff. Thereby mimicry is different from imitation since imitative behavior is the result of an intention to behave like the imitator. Whereas mimicry is the result of an intention to respect and follow norms and rules defined by organizational field as Powel and DiMaggio (1993).

Moreover, Smith and his colleagues $(1989,1991)$ maintain the idea that intensity of competitive reactions on a market depends on the similitude degree of these reactions with regard to the action. This implies the existence of several types of reactions depending on the "degree of similitude" of each reaction. We believe that both 
degree of similitude between action and reaction and the intentionality to imitate present two conditions required and complementary to the condition of advanced time developed by Haunschild (1993). Based upon these articles, our definition of imitation introduces (1) the concept of the "continuation" in adopting practices, (2) the "degree of similitude" between practices adopted by the innovator and the imitator, (3) the "intentionality" of organizations to imitate. This definition of imitation does not imply necessarily the perfect homogenization between imitators' practices and innovators' practices. Contrary to Haunschild' definition (1993), our definition allows to classify the different types of imitation identified in the literature.

To conclude this part, we present a Table 2 that synthesis our work of meta-analysis on the imitation and the innovation citations in big database. This table shows a large presence of the innovation compared with the imitation.

Table 2. Meta analysis of imitation and innovation

\begin{tabular}{|c|c|c|c|c|c|c|c|c|}
\hline & \multicolumn{8}{|c|}{ Data Base } \\
\hline & \multirow{2}{*}{\multicolumn{4}{|c|}{ Business source complete }} & \multicolumn{4}{|c|}{ Science direct } \\
\hline & & & & & (Busir & s, management & accounting, decis & sciences) \\
\hline & In the title & In the abstract & In the keywords & In the text & In the title & In the abstract & In the keywords & In the text \\
\hline Imitation & 630 & 2344 & 514 & 29624 & 133 & 373 & 137 & 7506 \\
\hline Mimetic & 52 & 325 & 8 & 3553 & 10 & 59 & 10 & 854 \\
\hline Mimicry & 74 & 219 & 38 & 3121 & 4 & 16 & 6 & 481 \\
\hline Imitate & 266 & 1310 & 8 & 20521 & 4 & 133 & 1 & 6076 \\
\hline Innovation & 38636 & 123829 & 122464 & 839401 & 4979 & 9961 & 4475 & 91113 \\
\hline
\end{tabular}

\section{Imitation between organizations on a competitive market}

In business and management science, a high number of articles (Westphal et al., 1997; Cornier \& Magnan, 2006; Williamson \& Cable, 2003; Stearns \& Allan, 1996; Vermeulen \& Wang, 2005; Broadbent et al., 2001; Salin, 2008; Greve, 2000) about organizations' homogenization in public sector or in highly regulated sectors like pharmaceutical industry or services to organizations concluded this similitude is due to isomorphism. On the other hand in other researches (Stearns \& Allan, 1996; Brandes et al., 2006; Srinivasan et al., 2007; Greve, 1995, 1996, 1998; Baize, 1996; Deephouse, 1999; Mouricou, 2009; Eapen \& Krishman, 2009) in competitive and private sectors, organization homogenization was explained by imitative behaviors either by a member of the organization or by the organization as it whole. From then on, our work concerns a particular type of inter-organizational imitation in strategic management field. It relates to imitation between organizations in a competitive market, qualified as "competitive imitation" (Mouricou, 2009) without coercive and normative pressures in accordance with Powell and DiMaggio (1983).

Many concepts are associated to imitation: replica, copy, reproduction, plagiarism, fake, forgery, pracy, spreading and standard. Speaking about implication implies either a perfect or a partial homogenization of practices. The two conditions we associate to Haunschild's definition (1993) are (i) the "degree of similitude" which allows classifying the different types of imitation between imitation and innovation on competitive markets, (ii) intentionality dimension that allows distinguishing mimicry from imitation and innovation.

Before enunciating these imitations' types, it would be right to illustrate the different types of imitation in a matrix composed by two dimensions. Each dimension corresponds to the two key concepts of our imitation's definition (Figure 1).

Intentionality to imitate or imitative behaviors of individuals within an organization is (are) the result of a rational intention. Imitators are not sheeps (Mouricou, 2006), they select the practice and the model to imitate depending on their resources, skills and also their strategic intention. The degree of similitude between the adopted practice by the imitative organization and the one adopted by innovative organization. In other words the relation between innovation and imitation. In this context, the mimicry we mentioned refers to a situation where similitude between two practices adopted by two organizations is important and the intentionality to imitate is weak. Normative and coercive pressures explain this similitude (DiMaggio \& Powell, 1983) without having the intention to imitate. 


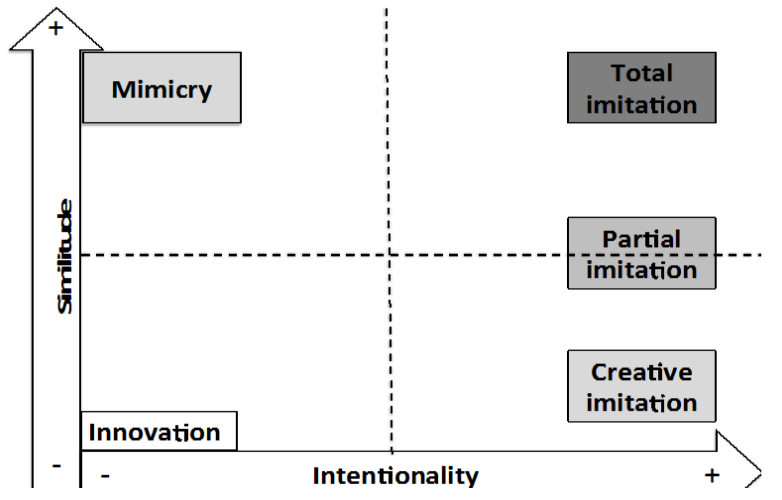

Fig. 1. Imitation matrix

Defining imitation according to these two variables allows distinguishing the different types of imitation in the literature. Similitude between the practices adopted by the innovative organization and then by the imitative organization is different in accordance with the mimicry or the imitation. This similitude is strong concerning mimicry. In this context, the homogenization of practices is often understood through isomorphism pressures proceeding from the institutional environment (norms, regulations, values). On the other hand concerning imitation, the similitude between an adoption of a practice and its imitation is relative. This similitude depends on the type of imitation adopted. It is significant for a total imitation whereas it is insignificant for partial and creative imitations. The degree of similitude between innovation and imitation is a significant indicator to distinguish all types of imitations. Nevertheless, it is inadequate to make a distinction between mimicry and imitation. Another indicator was crossed with the similitude. This indicator is the organization intentionality to imitate. Indeed, an organization can adopt an existing practice without being conscious of its existence. So the intentionality to imitate is an additional critical variable to consider imitation as the origin of homogenization. Thanks to this variable the difference between mimicry, innovation and imitation can be noticed (Figure 1). Whatever the type of imitation the intentionality to imitate, the intentionality to imitate exists in a certain level. In other words, a product cannot be considered as the result of an imitative behavior without showing the intention or the willingness of an organization to imitate. If there is no intention to imitate though a similitude can be identified, we then speak about mimicry. So as to better illustrate the difference between imitation and mimicry, innovation was positioned in the extremity of the total imitation. This position is justified because the degree of similitude between two innovations is almost nonexistent and indeed the intention to imitate is missing.
In order to group together the different types of imitation, the concept of "hyper imitation" that we defined as the situation where an organization in a market imitate perfectly a competitor's product or partially another product from a competitor. This situation has been examined in certain American industries in electronic, information technology, telecommunication and computing materiel. Lee and Zhou (2012) developed the performance of imitative organizations while Posen et al. (2013) developed a simulation of actions and reactions on a sample of fifteen firms.

2.1. Total imitation. Imitation aims to destruct the innovator advantage. The imitation can create profitable asymmetries with the aid of microchanges in the practice or the product characteristics (Philippe, 1984). Imitation is profitable since it allows the imitator to avoid the investments in R\&D and the risks inherent in the creation of a market. In literature for some researchers, imitation is defined as a simple copy identical to the innovation. For others, it is characterized as a copy of particular elements of an innovative organization's practice with the preservation of a differentiation in terms of functioning, implementation, price, and advertising concerning a product (Shnaars, 1994). This previous definition is often identified in the articles on imitative behaviors in service companies. A company imitates totally a service with distinguished commercial policies. However on goods' market, a total or partial imitation can be associated with the forgery considered like falsification and it can also be considered as legal in case of missing or expired legal barriers to imitation (Schnaars, 1994).

The innovative organization is not directly treated by the imitative organization as long as it does not attack it frontally since on the one hand, a patented innovation is protected against perfect imitations; and on the other hand, an imitative reaction (total imitation) on a market is less intense than the other imitative reactions (partial and creative) (Schnaars, 1994; Lee \& Zhou, 2012).

For Posen et al. (2013), the perfect imitation represents the unilateral uptake of a flow of information from the innovative organization to the imitative organization. Only information and knowledge from an innovator are included in the process of a total imitation. This imitation is the total and unique exploitation of information and knowledge from the innovator (Philippe, 1984). This imitation type is also defined as a pure imitation of a new idea and the result of this idea (Bolton, 1993). 
2.2. Partial imitation. In this perspective, which is different from that of total imitation, we take an interest in the degree of similitude between an action and a reaction. The imitation is not a simple "sheep behavior" (Mouricou, 2006). An organization can remake an existent thing without being in the situation of a perfect similitude just by practicing a strategy of partial differentiation or partial homogenization. In the same direction, Baize defined imitation as a strategy "to adopt certain characteristics of the original product" (1999, p. 78).

With a pure imitation, an organization can never achieve a competitive advantage (Posen \& al., 2013). According to this author, the acquisition of a competitive advantage depends on the type imitation. Whyte's contribution is theoretical since in the business world when a large firm imitates with marketing capacities and product development, it can even destroy the innovator and overtake him.

This reasoning is defended by Schnaars (1994). In accordance with Deephouse (1999), the banks that are the most successful are those located in an intermediate position: partially differenced and partially identical to the competitors' position. We consider this imitation as "partial". In order to illustrate this imitation type the Wiko example appears particular significant. On the French market of smartphones, Wiko is typically an imitative firm with its "low cost business model". In 2011, it marketed smartphones similar to those of Samsung. Then, it launched smartphones with large screen by intending to partially imitate the two major actors on this market (Samsung and Apple) with a mixture of characteristics and design from them. Wiko was not able to overtake them nonetheless it managed to reach the third rank in 2013 overtaking other brands like Nokia and Sony. It took advantage of its partnership with a Chinese manufacturer to produce low cost smartphones with particular differentiation. For instance, Wiko was the first to sell smartphones with two smart cards.

2.3. Creative imitation. Imitate does not mean stopping to create. Bolton (1993) underlines two acts in imitation: the "following" act and the "appropriation" act. Le Duff and Maisseu (1991) defined imitation as an appropriation by others of the novelty introduced by the innovative company. Beyond these articles, Philippe (1984) considers imitation as an advanced innovation. In our point of view, creative imitation appears to be just like a "dependent" innovation of knowledge and information coming from the innovator.

Adaptation of an imitation consists in making a smart and innovative duplicate of an idea. In this case, the imitation is considered as an action that generates a competitive advantage for an imitative organization. It is a matter of an imitation exclusively of the ideas and not of the results of these ideas. Regarding a new product (A) on a market (B), the creative imitation can consist in imitating the product (A) but on a market (B'). Another case proves to be possible when a firm can implement an international organizational mode to the national level. The apparition of personal computers in 1977 is originally a strategy of "creative" of American constructor MITS and apple (Schnaars, 1994). Those researchers described the action of creating personal computer as an "adaptive imitation" of central computers existing in the market. However since the usage of computer became commercial in 1981, IBM entered the market and dominated it quickly thanks to its reputation and skills on central computers segment.

In order to intelligently imitate, the organization can adopt or reform the innovator's products (Kotler, 1997). It can choose to commercialize these products on other markets and thus avoid a direct confrontation with the innovative organization. The company can also develop itself as a future leader. For instance, certain Japanese companies, in particular Canon and Nikon, managed to be leaders on the market of $35 \mathrm{~mm}$ cameras thanks to the adaption and improvement of the products developed by Leica in 1925 (Schnaars, 1994). Leica was the leader on the market on this market during decades until the Japanese adapted imitation came up with important improvements and a price reduction. The innovator did not react and finish as accessories fabricant.

An opposed to the other types or other dimensions of imitation, the R\&D is a determinant factor of a "creative" imitative. As Gallaud and Nayaradou (2011) show, the R\&D is essential to appropriate an innovation. In that case, imitators do not imitate to reproduce the same thing as the imitator but to produce something better. The imitation is not just a simple reaction, but it is an action as well. We endorse Levitt idea that on a market only one innovator exists and the others are imitators of the creation. This is described as an innovative imitation (Levitt, 1966).

Our objective is to improve the knowledge on phenomena of competitive imitation in management and not to challenge the articles on imitation. This new conception of imitation is more part of strategic aspects of imitative companies. In this article, as opposed to the idea that the strategy of a company does not result only from the imitation, we suggest that imitation can be one of the intentional choices of companies on competitive markets. 
Table 3. The characteristics and the concepts associating to other types of imitation

\begin{tabular}{|l|l|l|l|}
\cline { 2 - 4 } \multicolumn{1}{c|}{} & \multicolumn{1}{c|}{ Total imitation } & \multicolumn{1}{c|}{ Partial imitation } \\
\cline { 2 - 5 } \multicolumn{1}{c|}{$\begin{array}{l}\text { Degree of similitude in } \\
\text { relation to the innovation }\end{array}$} & Strong & Average & Weak \\
\hline Knowledge source & External & Internal and external & \multicolumn{1}{c|}{ Creative imitation } \\
\hline R\&D imitative investments & $\begin{array}{l}\text { Null } \\
\text { (Ravichandran and Madanmohan, } \\
\text { 2001) }\end{array}$ & $\begin{array}{l}\text { Weak } \\
\text { (Ravichandran and Madanmohan, 2001) }\end{array}$ & $\begin{array}{l}\text { Average } \\
\text { (Ravichandran and Madanmohan, 2001; } \\
\text { Schnaars, 1994; Gallaud and Nayaradou, } \\
\text { 2011) }\end{array}$ \\
\hline Purpose & $\begin{array}{l}\text { Detroy the competition advantage } \\
\text { of innovative organization } \\
\text { (Cherchem, 2012; Schnaars, 1994; } \\
\text { Porter, 1982) }\end{array}$ & $\begin{array}{l}\text { Maintain a competitive parity (Ma et Karri, } \\
\text { 2005; Posen et al., 2013; Haunschild et } \\
\text { Miner, 1997; Greve, 1996; Mouricou, 2009) }\end{array}$ & $\begin{array}{l}\text { Obtain a competitive advantage } \\
\text { (Schnaars, 1994) }\end{array}$ \\
\hline Associated concepts & $\begin{array}{l}\text { Perfect imitation (Posen et al., } \\
\text { 2013; Julien, 1995); Blind imitation } \\
\text { (Li et Kozhikode, 2008) Pure } \\
\text { imitation (Lee et Zhou, 2012; } \\
\text { Bolton, 1993) }\end{array}$ & $\begin{array}{l}\text { Reflective imitation (Bolton, 1993); marginal } \\
\text { imitation (Valdani et Arbore, 2007); partial } \\
\text { homogenization (Deephouse, 1999); } \\
\text { Imperfect imitation (Posen et al., 2013) }\end{array}$ & $\begin{array}{l}\text { Advance innovation (Philippe, 1984); } \\
\text { Intlligence imitation (Kolter, 1997); } \\
\text { adnnovtive imitation (Kolter, 1997); } \\
\text { Imovation (Shitation (Levitt, 1966); } \\
\text { imitation (Valdani et Arbore, 2007) }\end{array}$ \\
\hline
\end{tabular}

\section{Conclusion}

The imitation is often considered as a simple behavior for neo-institutionalist and as a simple characteristic of a reaction by theoreticians of dynamic competition. In this research, we intended to show imitation is an intentional, voluntary and strategic choice. This theoretical contribution will allow future researchers interested in approaching the topic imitative behavior of companies to better frame their research and to take into consideration the strategic aspect of imitation.

Through this article, we hope we have clarified the concept of imitation to distinguish it from other concepts, in particular the concept of mimicry that is often associated to imitation. Duplicating a competitor is not the only possible imitation on competitive markets. There are also imperfect imitations and creative imitations.

We would like to encourage researchers to approach this topic of imitation in the strategic management field. We recommend not using the word "imitation" without specifying its dimension in order to increase the theoretical validity of the research. If it is not specified we suggest using the notion of hyper imitation that can be used to regroup all the types of imitation in one single market.

\section{References}

1. Abrahamson, E. (1996). Management fashion. Academy of Management Review, 21(1), 254-285.

2. Augarten, S. (1984). Bit by Bit: an illustrated history of computers. New York: Ticknor \& Fields.

3. Baize, D. (1999). De la contrefaçon à l'imitation. Revue française de Gestion, 119(25), 76-81.

4. Banerjee, A. V. (1992). A simple model of herd behavior. Quarterly Journal of Economics, 107(3), $797-817$.

5. Barney, J. B. (1991). Firm Resources and Sustained Competitive Advantage. Journal of Management, 17(1), 99-120.

6. Baudonnière, P. M. (1997). Le mimétisme et l'imitation. Paris: Dominos Flammarion.

7. Bensebaa, F. (2000). Actions stratégiques et réactions des enterprises. Management, 3(2), 57-79.

8. Bikhchandani, S., Hirshleifer, D., \& Welch, I. (1992). A theory of fads, fashion, custom, and cultural change as informational cascades. Journal of Political Economy, 100(5), 992-1026.

9. Bolton, M. K. (1993). Imitation versus Innovation: lessons to be learned from the Japanese. Organizational Dynamics, 21(3), 30-45.

10. Brandes, P., Hadani, M., \& Goranova, M. (2006). Stock options expensing: An examination of agency and institutional theory explanations. Journal of Business Research, 59(5), 595-603.

11. Broadbent, J., Jacobs, K., \& Laughlin, R. (2001). Organizational resistance strategies to unwanted accounting and finance changes. Accounting, Auditing and Accountability Journal, 14(5), 565-586.

12. Cadix, A. \& Pointet, J. M. (2002). Le management à l'épreuve des changements technologiques. Impacts sur la société et les organizations. Paris: Organisation.

13. Carpenter, G. S., \& Nakamoto, K. (1989). Consumer preference formation and pioneer advantage. Journal of Marketing Research, 26(3), 285-298.

14. Damanpour, F. (1991). Organizational innovation: a meta-analysis of effects of determinants and moderators. Academy of Management Journal, 34(3), 555-590. 
15. Deephouse, D. L. (1999). To be different, or to be the same? It's a question (and theory) of strategic balance. Strategic Management Journal, 20(2), 147-166.

16. Delios A., \& Henisz, W. (2001). Uncertainty, imitation and plant location: Japanese multinational corporations 1990-1996. Administrative Science Quarterly, 46(3), 443-475.

17. Dimaggio, P. J., \& Powell, W. W. (1983). The iron cage revisited: Institutional isomorphism and collective rationality in organizational fields. American Sociological Review, 48(2), 147-160.

18. Dolphin, R. (1987). Photography's March of Time, Maclean's, April 24, 51-52.

19. Garcia-Pont, C., \& Nohria, N. (2002). Local versus global mimetism: the dynamics of alliance formation in the automobile industry. Strategic Management Journal, 23(4), 307-321.

20. Greenberg, C. (1992). Future Worth: Before It's Hot, Grab It. New York Times, April 16, p. 19.

21. Greve, H. R. (1995). Jumping ship: The diffusion of strategy abandonment. Administrative Science Quarterly, 40(3), 444-473.

22. Haunschild, P. R. (1993). Interorganizational Imitation: The impact of interlocks on corporate acquisition activity. Administrative Science Quarterly, 38(4), 564-592.

23. Haunschild, P. R., \& Miner, A. S. (1997). Modes of Interorganizational Imitation: The Effects of Outcome Salience and Uncertainty. Administrative Science Quarterly, 42(3), 472-500.

24. Haveman, H. A. (1993). Follow the Leader: Mimetic Isomorphism and Entry into New Markets. Administrative Science Quarterly, 38(4), 593-627.

25. Henderson, R., \& Cockburn, I. (1994). Measuring competence? Exploring firm effects in pharmaceutical research. Strategic Management Journal, 15(8), 63-84.

26. Hippel, V. E. (1982). Appropriability of innovation benefit as a predictor of the source of innovation. Research Policy, 11(2), 95-115.

27. Hoppe, H. U., Gaßner, K., Mühlenbrock, M., \& Tewissen, F. (2000). Distributed Visual Language Environments for Cooperation and Learning. Applications and Intelligent Support. Group Decision and Negotiation Journal, 9(3), 205-220.

28. Julien, E. (1996). Imitation et appropriation dans les dynamiques industrielles, Le cas de l'industrie des Semences, Thèse de Doctorat École Nationale des Mines de Paris.

29. Koenig, G. (1996). Management stratégique. Paradoxes, interactions et apprentissages. Paris: Nathan.

30. Kotler, P. (1997). Marketing management: Analysis, planning and control. New York: Prentice Hall.

31. Le Bon, G. (1895). Psychologie des foules. Paris: Felix Alcan.

32. Le Duff, R., \& Maisseu, A. (1991). Management technologique. Paris: Sirey.

33. Lee, R. P., \& Zhou, K. Z. (2012). Is Product Imitation Good for Firm Performance? An Examination of Product Imitation Types and Contingency Factors. Journal of International Marketing, 20(3), 1-16.

34. Levitt, B., \& March, J. (1988). Organizational learning. Annual Review of Sociology, 14(1988), 319-340.

35. Levitt, T. (1966). Innovation imitation. Harvard Business Review, 44(5), 63-70.

36. Li, J., \& Kozhikode, R. K. (2008). Knowledge management and innovation strategy: The challenge for latecomers in emerging economies. Asia Pacific Journal of Management, 25(3), 429-450.

37. Lieberman, M., \& Montgomery, D. (1988). First-Mover Advantages. Strategic Management Journal, 9(51), 41-58.

38. Mansfield, E. (1985). How Rapidly does New Industrial Technology Leak Out? Journal of Industrial Economics, 34(2), 217-223.

39. Mansfield, E., Schwartz, M. \& Wagner, S. (1981). Imitation costs and patents: an empirical study. Economic Journal, 91(364), 907-918.

40. Mouricou, P. (2006). Toujours la même chanson: Les logiques mimétiques des radios musicales. Revue française de Gestion, 32(164), 77-94.

41. Ordanini, A., Rubera, G. \& DeFillippi, R. (2008). The Many Moods of Inter-Organizational Imitation: A Critical Review. International Journal of Management Reviews, 10(4), 375-398.

42. Padioleau, J. G., (2002). La fin des Sapeurs-Pompiers républicains? Paris: L'Harmattan.

43. Philippe, L. L. (1984). L’imitation des modernes - typographies II. Paris: Galiliée.

44. Porter, M. E. (1986). L'Avantage concurrentiel : comment devancer ses concurrents et maintenir son avance. Paris: InterEditions.

45. Porter, M. E. (1996). What is Strategy? Harvard Business Review, 74(6), 61-78.

46. Posen, H. E., Lee, J., \& Yi, S. (2013). The power of imperfect imitation. Strategic Management Journal, 34(2), 149-164.

47. Reed, R. \& DeFillippi, R. (1990). Causal ambiguity, barriers to imitation, and sustainable competitive advantage. Academy of Management Review, 15(1), 88-102.

48. Schnaars, S. P. (1994), Managing imitation strategies. New York: The Free Press.

49. Semadeni, M. \& Anderson, B. S. (2010). The Followers' Dilemma: Innovation and Imitation in the Professional Services Industry. Academy of Management Journal, 53(5), 54-70.

50. Serling, R. (1982). The Jet Age. Alexandria, Va., Time-Life Books. 
51. Srinivasan, R., Haunschild, P. \& Grewal, R. (2007). Vicarious learning in new product introductions in the early years of a converging market. Management Science, 53(1), 16-28.

52. Stearns, L. B. \& Allan, K. D. (1996). Economic behavior in institutional environments: The corporate merger wave of the 1980s. American Sociological Review, 61(4), 699-718.

53. Tarde, G. (1890). Les lois de l'imitation: étude sociologique. Paris: Felix Alcan.

54. Teece, D. J., Pisano, G., \& Shuen, A. (1997). Dynamic capabilities and strategic management. Strategic Management Journal, 18(7), 509-533.

55. Therien, L. (1993). Why Gateway Is Racing to Answer on the First Ring. Business Week, September 3, p. 92.

56. Tirole, J. (1990). The Theory of Industrial Organization. Cambridge: MIT Press.

57. Valdani, E., \& Arbore, A. (2007). Strategies of imitation: an insight. Problems and Perspectives in Management, 5(3), 198-206. Retrieved from: http://businessperspectives.org/journals/problems-andperspectives-in-management/issue-3-cont/strategies-of-imitation-an-insight

58. Westphal, J. D., Gulati, R., \& Shortell, S. M. (1997). Customization or conformity? An institutional and network perspective on the content and consequences of tqm adoption. Administrative Science Quarterly, 42(2), 366-394.

59. Whyte, W. F. (1968). Imitation or innovation: Reflections on the institutional development of Peru. Administrative Science Quarterly, 13(3), 370-385. 